\title{
Analisis Pengaruh Kinerja Keuangan Terhadap Financial Distress Pada Perusahaan Tekstil dan Garment Di BEI
}

\author{
Muhamad Fatikh Satrio Ardi ${ }^{1}$ ), Desmintari ${ }^{2}$ ), Fitri Yetty ${ }^{3}$ ) \\ Fakultas Ekonomi dan Bisnis, Universitas Pembangunan Nasional Veteran Jakarta \\ EMail: 1'satriaardii@gmail.com, ${ }^{2}$ desmintari@yahoo.com, ${ }^{3}$ fitriyetty_61@yahoo.com
}

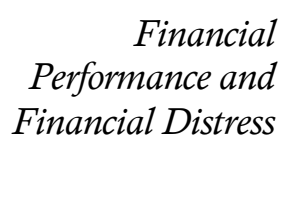

309

Submitted:

SEPTEMBER 2020

Accepted:

NOVEMBER 2020

\begin{abstract}
ABSTRAK
Penelitian ini merupakan penelitian kuantitatif bertujuan untuk mengetahui pengaruh likuiditas, leverage, dan profitabilitas terhadap financial distress. Sampel yang digunakan adalah perusahaan sub sektor properti dan real estate. Variabel dependent yang digunakan yaitu financial distress, sedangkan variabel independentnya yaitu, likuiditas yang diukur dengan Rasio Lancar atau Current Ratio (CR), leverage yang diukur dengan debt to total asset ratio dan profitabilitas yang diukur dengan return on asset ratio. Metode penentuan sampel yang digunakan dalam adalah metode purposive sampling. Dengan jumlah sampel akhir sebanyak 27 perusahaan Tekstil dan garment. Jenis data dalam penelitian ini ialah data sekunder. Untuk menguji hipotesis menggunakan Analisis Regresi Logistik dengan program Eviews 10.0. Hasil dari pengujian di peroleh hasil bahwa tidak terdapat pengaruh antara Leverage dan Profitabilitas terhadap financial distress, dan terdapat pengaruh negatif antara Likuiditas dan financial distress.
\end{abstract}

Kata Kunci : Financial Distress, Likuiditas, Leverage, Profitabilitas, Logistik.

\section{ABSTRACT}

This research is using quantitative study aimed to see the influence of liquidity, leverage, and profitability on financial distress. This research using textile and garment company that listed in Indonesian Stock Exchange as sample. The dependent variable in this study is financial distress and the independent variable in this study is liquidity that measured by current ratio, leverage that measured by debt to total asset ratio and profitability that measured by return on asset ratio. The sampling method in this study is using purposive sampling method. The sample used in this study is 17 Textile and garment company. The type of data used on this study is secondary data. This study is using Regression Logistic Analisys to testing the hypothesis. The result on this research is there are no influence of Leverage and Profitability to financial distress, and there is negative influence of Liquidity to financial distress.

Keywords : liquidity, leverage, profitabily, financial distress, logistic

\section{PENDAHULUAN}

Persaingan bisnis merupakan suatu hal normal. Persaingan bisnis dapat terjadi dikarenakan adanya pelaku usaha yang satu, dengan yang lainnya memiliki kesamaan di bidang usaha. Hal ini bisa menjadi suatu hal baik dan juga suatu hal yang tidak baik. Sesuatu yang baik adalah si pelaku usaha bisa memacu perusahaannya untuk membuat sebuah produk yang unggul dibanding yang lainnya. Namun apabila persaingan bisnis yang tidak baik adalah ketika pengusaha tidak mampu dalam memproduksi produk yang unggul dikarenakan faktor-faktor yang tidak mampu di penuhi, sehingga menyebabkan perusahaan tersebut kalah bersaing. Dan berdampak pada turunnya laba perusahaan.

\section{JIAKES}


Financial

Performance and

Financial Distress

Seperti halnya yang terjadi pada Industri Tekstil dan Garment. Belakangan ini sedang mengalami penurunan kinerja dikarenakan banyaknya impor yang masuk ketimbang dengan ekspor yang keluar. hal ini tentunya sangat berdampak pada perekonomian Indonesia. Data Badan Pusat Statistik (BPS) menyatakan bahwa volume impor kain meningkat selama periode 2016-2018. Tren kenaikan tercatat rata-rata sebesar 31,80 persen per tahun.Pada 2016, lalu impor kain tercatat sebesar 238.219 ton, kemudian meingkat menjadi 291.915 ton pada 2017. Impor kain kembali tumbuh menjadi 413.813 ton pada 2018. Volume impor kain Indonesia terbesar berasal dari China dengan pangsa impor sebesar 67,86 persen pada 2018. Selain China, Indonesia juga mengimpor kain dari Taiwan, Hong Kong, dan Korea Selatan (cnnindonesia.com).

Adapun menurut Asosiasi Pertekstilan Indonesia (API) dalam kurun waktu 2018 sampai 2019 telah mendata bahwa 9 pabrik tekstil tutup usaha akibat kalah bersaing dengan produk impor. (cnnindonesia.com) Era globalisasi mengakibatkan hilangnya batasan-batasan dalam wilayah maupun negara, setiap orang dapat melakukan transaksi ke luar dengan mudah. Perusahan luar pun dapat melakukan promosi-promosi ke dalam sehingga menyebabkan terjadinya Ke-ketat-an dalam persaingan dengan produk impor, yang menyebabkan beberapa produk lokal menjadi sedikit tersingkir dengan produk impor karna dikatakan bahwa produk impor lebih baik kualitasnya dibandingkan dengan produk lokal. Padahal tidak juga seperti itu. Lalu Hal ini yang menyebabkan pengusahapengusaha tekstil dan garment dalam mengalami penurunan laba.

Perusahaan Perusahaan menjadi perhatian penting bagi pegawai, pemerintah, investor, nasabah bank dan otoritas pembuat regulasi. Oleh karenanya, dalam model peringatan dini (early warning system) dapat berguna sebagai informasi awal untuk mengantisipasi kondinis financial distress. Model ini bisa digunakan sebagai sarana pengidentifikasian saat terjadinya kesulitan keuangan sejak awal bahkan untuk memperbaiki kondisi perusahaan (Fahmi, 2014, Hlm 93) mendefinisikan financial distress 'merupakan tahap menurunnya keadaan keuangan yang terjadi saat sebelum terjadinya kebangkrutan atau likuiditasi'. Kondisi tersebut mengindikasikan suatu perusahaan sedang mengalami kesulitan keuangan (financial distress) yang pada akhirnya jika perusahaan tidak mampu keluar dari kondisi tersebut di atas, maka perusahaan tersebut akan mengalami kepailitan.

Financial Distress sendiri bisa di prediksi dengan melihat kinerja keuangan perusahaannya, diantaranya likuiditas, leverage, dan profitabilitas.

Pertama, yaitu likuiditas, likuiditas sendiri diartikan sebagai kemampuan perusahaan melakukan pemenuhan kewajiban kewajiban perusahaan jangka pendek. Apabila likuiditas suatu perusahaan kecil maka dapat mengindikasikan bahwa asset perusahaan tidak dapat menutupi Hutang perusahaan. Sehingga perusahaan tidak dapat melunasi Hutangnya. Dimana apabila perusahaan mengalami penurunan dalam likuiditasnya, maka terdapat risiko adanya financial distress pada perusahaan tersebut.

Yang kedua yaitu profitabilitas, diartikan sebagai suatu kemampuan perusahaan dalam mencetak laba dengan memaksimalkan aset-aset perusahaan dan modal saham tertentu. Perusahaan dengan nilai profitabilitas yang tinggi dan positif menunjukkan perusahaan tersebut telah baik dalam mencetak laba. Namun sebaliknya jika perusahaan profitabilitasnya kecil dan negatif maka perusahaan tersebut terinditifikasi Financial Distress.

Yang ketiga yaitu leverage, adalah rasio yang menggambarkan seberapa mampu perusahan mengalokasikan hutangnya pada kegiatan operasional perusahaanya dan aktiva-aktiva perusahaan. leverage menunjukan berapa besar kegiatan operasional perusahaan dipenuhi oleh utang. Dimana apabila nilai leverage suatu perusahaan tinggi dapat mengakibatkan tingginya juga risiko perusahaan mengalami financial distress.

Peneliti akan melakukan sebuah penelitian berdasarkan penelitian yang sudah ada sebelumnya yang menunjukan masih adanya perbedaan (Gap Research) mengenai Analisis Profitabilitas, Likuiditas dan Leverage terhadap Financial Distress. Penelitian ini dilakukan atas dasar kaingin tahuan peneliti bahwasannya seberapa bepengaruh 
Profitabilitas, likuditas dan leverage dalam mempengaruhi financial distress. Peneliti memilih Perusahaan Tekstil dan Garment yang terdaftar di BEI sebagai objek Penelitian

Berikut merupakan hasil Penelitian yang sudah dilakukan terlebih dahulu yang mendukung topik penelitian kali ini yang pertama oleh Fatimah, Akhmad Toha, Aryo Prakoso (2019) yang berjudul "The Influence Of Liquidity, Leverage, And Profitability Ratio On Financial Distress" mengatakan bahwa Likuiditas tidak berpengaruh terhadap financial distress. Profitabilitas tidak berpengaruh terhadap Financial distress. Namun Leverage berpangaruh terhadap Financial distress. Selanjutnya peneliti yang dilakukan oleh Winwin Yadiati (2017) "The Influence Of Profitability On Financial Distress : A Research On Agricultural Companies Listed In Indonesian Stock Exchange" yang berfokus pada Profitabilitas mengemukakan bahwa Profitabilitas berpengaruh namun tidak signifikan terhadap Financial Distress. Dan ada penelitian yang dilakukan oleh Erni MAsdupi, Abel Tasman, Atri Davista (2018) dengan judul "Pengaruh Likuiditas, Leverage, Dan Profitabilitaas Terhadap Financial Distress Perusahaan Manufaktur Yang Terdaftar Di Bei". Mengatakan bahwa Profitabilitas, Leverage dan Likuiditas, seluruhnya berpengaruh Negatif signifikan terhadap Financial Distress.

Mengetahui Bersama bahwasannya kondisi Tekstil dan Garment sedang mengalami penurunan maka penelitian ini dilakukan untuk memprediksi perusahaan-perusahaan tekstil dan garment yang terdaftar di BEI mana saja yang akan mengalami kondisi kesulitan keuangan dengan melihat Profitabilitas, Likuiditas dan Leverage dalam laporan keuangan tersebut. Dengan melihat data keuangan tahun 2016 hingga 2018.

Berdasarkan Latar Belakang yang telah dijabarkan diatas serta Gap Research yang masih ada maka peneliti tertarik untuk melakukan penelitian lebih lajut dengan Perusahaan Tekstil dan Garmnet sebagai objek penelitiannya. Tujuan penelitian ini untuk melakukan Analisa Pengaruh Kinerja Keuangan Terhadap Financial Distress pada perusahaan Tekstil Dan Garment yang terdaftar di BEI"

\section{Model Penelitian Empirik}

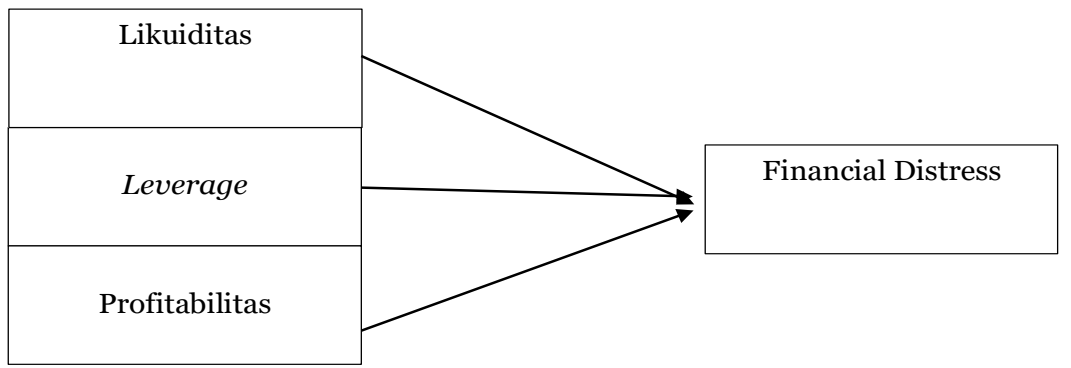

Gambar 1. Model Penelitian Empirik

\section{Hipotesis}

Hipotesis merupakan jawaban sementara dari rumusan masalah. Dari model penelitian empiris diatas, dapat disimpulkan hipotesis pada penelitian ini adalah:

H1 : Rasio Likuiditas berpengaruh Negatif terhadap Financial Distress

H2 : Rasio Profitabilitas berpengaruh Positif terhadap Financial Distress

H3 : Rasio Leverage berpengaruh positif terhadap Financial Distress

\section{METODE PENELITIAN}

\section{Populasi dan Sampel}

Populasi yang digunakan dalam penelitian ini yaitu perusahaan tekstil dan garment yang terdaftar di Bursa Efek Indonesia. Dengan periode laporan keuangan tahun 20162018.

\section{Pengukuran Variabel}

Financial distress merupakan kondisi keuangan yang sedang bermasalah dalam suatu perusahaan sebelum tahapan kebangkrutan perusahaan tersebut.Pengukuran financial distress mengunakan Model Altman Z-score Revisi yang menggunakan variabel dummy dengan ukuran nol (0) apabila terjadi financial distress dan satu (1) apabila perusahaan
Performance and

Financial Distress 
Financial

Performance and

Financial Distress

Dimana:

tidak mengalami financial distress dalam penelitian ini indikator financial distress adalah sebagau berikut:

$$
\mathrm{Z}=0,717\left(X_{1}\right)+0,874\left(X_{2}\right)+3,107\left(X_{3}\right)+0,420\left(X_{4}\right)+0,998\left(X_{5}\right)
$$

$Z=$ Financial Distress Index

$X_{1}=$ Working Capital to Total Assets

312

$X_{2}=$ Retained Earnings to Total Assets

$X_{3}=$ Earning Before Interest and Taxes to Total Assets

$X_{4}=$ Book Value of Equity to Book Value of Debt

$X_{5}=$ Sales to Total Assets

Kriteria yang digunakan untuk memprediksi kebangkrutan perusahaan dengan model diskriminan adalah dengan melihat zone of ignorance yaitu daerah nilai Z. Dimana dikategorikan pada berikut ini:

a. Jika nilai $Z>2,90$ Maka perusahaan tersebut dikategorikan tidak bangkrut

b. Jika nilai $1,20<Z<2,90$ Maka perusahaan tersebut dikategorikan sebagai perusahaan rawan bangkrut atau Grey Area

c. Jika Nilai $\mathrm{Z}<1,20$ Maka perusahaan tersebut dikategorikan sebagai perusahaan bangkrut

Variabel Independen

a. Rasio Likuiditas (X1)

Rasio Likuiditas ialah rasio yang digunakan untuk menilai seberapa tingkat kemampuan suatu perusahaan dalam memenuhi kewajiban jangka pendek. Dalam penelitian ini Rumus yang digunakan adalah berikut:

b. Rasio Leverage (X2)

$$
\text { Current Rasio }=\frac{\text { Current Asset }}{\text { Current Liabilities }}
$$

Rasio Leverage adalah rasio yang menggambarkan seberapa mampu perusahan mengalokasikan hutangnya untuk kegiatan operasional perusahaan dan aktivaaktiva perusahaan. Dalam penelitian ini Rumus yang digunakan sebagai berikut:

c. Rasio Profitabilitas (X3)

$$
\text { Debt to Assets Ratio }=\frac{\text { Total Utang (DEBT) }}{\text { Assets }}
$$

Profitabilitas merupakan suatu kemampuan perusahaan dalam mencetak laba dengan memaksimalkan aset-aset perusahaan dan modal saham tertentu. Untuk mengukur kemampuan perusahaan menghasilkan laba maka di dalam penelitian ini Profitabilitas diukur menggunakan rumus Return On Asset. Berikut adalah rumusnya:

\section{Teknik Pengumpulan Data}

$$
\text { Return on Assets }=\frac{\text { EAT }}{\text { Total asset }}
$$

Jenis data yang digunakan dalam penelitian ini adalah data sekunder, dimana data ini diambil dari dokumen yang bisa secara langsung digunakan. Data dalam penelitian ini berupa laporan kinerja dan laporan tahunan yang dipublikasikan selama 3 tahun berturutturut pada dimulai dari periode 2016 sampai 2018 yang diakses melalui situs Bursa Efek Indonesia (www.idx.co.id) serta sumber lainnya yang relevan.

\section{Teknik Analisis}

Teknik analisis yang digunakan untuk penelitian ini dengan aplikasi Microsoft Office Excel 2019, E-views 10, dan menggunakan metode analisis regresi logistik.

\section{Statistik Deskriptif}

Analsis deskriptif dipergunakan untuk memberikan deskripsi atau gambaran dari suatu data yang dilihat rata-rata (mean),standar deviasi, varian, maksimum, minimum, sum, range, kurtosis dan skewness.

\section{Metode Analisis Regresi Logit}

Analisis regresi merupakan teknik analisa yang digunakan untuk menjelaskan pengaruh antar variabel.Pada penelitian ini peneliti menggunakan metode analisis regresi 
logit, metode regresi logit digunakan pada penelitian ini karena adanya variabel dependen yang bersifat dikotomi adapun yang dimaksud dengan variabel dikotomi yaitu dengan adanya 2 kategori yang pada penilitian ini kategori 0 untuk perusahaan financial distress dan kategori 1 untuk perusahaan yang tidak mengalami financial distress.

$$
\operatorname{Ln}\left(\frac{P i}{1-p i}\right)=\beta_{0}+\beta_{1} X_{1}+\beta_{2} X_{2}+\beta_{3} X_{3}
$$

Keterangan :

$\operatorname{Ln}\left(\frac{P i}{1-p i}\right)$

$=$ Log dari perbadingan perusahaan yang mengalami financial distress dan perusahaan yang tidak mengalami financial distress

$\beta_{0}$

$\beta_{1}$

$\beta_{2}$

$\beta_{3}$

$X_{1}$

$X_{2}$

$X_{3}$

= Konstanta

$=$ Koefisien Regresi Likuditas

= Koefisien Regresi Leverage

$=$ Koefisien Regresi Profitabilitas

$=$ Likuiditas

$=$ Leverage

$=$ Profitabilitas

\section{HASIL DAN PEMBAHASAN}

\section{Deskripsi Objek Penelitian}

Objek Penelitian yaitu perusahaan Sub Sektor Tekstil dan Garment yang terdaftar di Bursa Efek Indonesia selama periode 2016-2018. Perusahaan Tekstil dan Garment yang terdaftar di bursa efek indonesia berjumlah 21 perusahaan. Namun, terdapat 4 perusahaan yang baru listing pada periode penelitian. Sehingga tidak termasuk kedalam populasi penelitian. Jadi, pada penelitian ini menggunakan 17 perusahaan Tekstil dan Garment

\section{Statistik Deskriptif}

Berdasarkan hasil Eviews versi 10 dalam mengelola data, dapat diperoleh hasil perhitungan sebagai berikut:

Tabel 2. Hasil Statistik Deskriptif

\begin{tabular}{lllll}
\hline & FD & CR & DAR & ROA \\
\hline Mean & 0.921569 & 1.728995 & 0.890975 & -0.01823 \\
\hline Maximum & 1.000000 & 6.456904 & 5.073297 & 0.141097 \\
\hline Minimum & 0.000000 & 0.10645 & 0.084951 & -0.6057 \\
\hline Std. Dev. & 0.271524 & 1.387747 & 1.104604 & 0.113387 \\
\hline
\end{tabular}

Sumber: data diolah dengan Eviews 10

Menurut dari hasil analisis statistik deskriptif diatas maka dapat diuraikan sebagai berikut:

a. Financial Distress

Berdasarkan Variabel Financial Distress (FD) di ukur menggunakan Altman Z-score Revisi. Berdasarakan hasil E-views pada 17 Perusahaan Tekstil dan garment diatas, diketahui bahwa nilai Financial Distress Rata-ratanya adalah 0.921569 Nilai Maximum variabel Financial Distress adalah 1.000000 artinya Financial Distress dan 0.000000 Artinya Non-Financial Distress. Perusahaan dengan nilai $\mathrm{Z}$ score tertinggi dengan nilai 5.425 yaitu pada perusahaan dengan kode TFCO pada tahun 2018, Perusahaan TFCO di kategorikan sebagai Non-Financial Distress. Hal ini dikarenakan nilai Altman Z-score lebih dari 2.90 yang menandakan perusahaan tersebut telah baik dan mampu dalam mengelola risiko kebangrkutan. Sementara nilai terendah pada variabel Financial Distress adalah -10.265 yaitu pada perusahaan dengan kode POLY pada tahun 2016, perusahaan POLY dikategorikan sebagai Financial Distress. Hal ini dikarenakan POLY memiliki nilai Altman Z-score kurang dari 1.20. yang menandakan perusahaan tersebut tidak mampu dan tidak baik dalam mengelola risiko kebangkrutan. 
Financial

Performance and

Financial Distress

$\underline{314}$ b. Likuiditas

Berdasarkan Variabel Likuiditas diukur dengan menggunakan Rasio Lancar atau Current Ratio. Berdasarkan hasil E-views pada 17 Perusahaan Tekstil dan Garment, diketahui bahwa rata-rata nilai Rasio Lancar adalah 1.728 dan Standar Deviasi sebesar 1.387 dimana nilai Standar deviasi lebih rendah dari rata-rata artinya tidak terjadi kesenjangan antara data satu dengan lainnya yang menandakan bahwa persebaran data sampel tidak ada kecenderungan data berbeda dengan satu dan lainnya. Nilai maximum Rasio Lancar adalah 6.456 yaitu pada perusahaan dengan kode PBRX pada tahun 2018. Hal ini menunjukan bahwa perusahaan tersebut telah mampu memenuhi kewajiban jangka pendeknya dikarenakan nilai Rasio Lancar PBRX lebih tinggi dibandingkan nilai rata-rata Rasio Lancar.. Nilai Minimum Rasio Lancar 0.106 ada pada perusahaan dengan kode HDTX pada tahun 2016. Hal ini menunjukan bahwa perusahaan tersebut tidak mampu dalam memenuhi kewajiban jangka pendeknya karena rata-rata nilai rasio lancar HDTX lebih rendah dibandingkan nilai rata-rata rasio lancar.

c. Leverage

Variabel Leverage diukur dengan menggunakan Rasio DAR atau Debt Assets Ratio. Berdarsarkan hasil E-Views pada 17 Perusahaan Tekstil dan Garment, diketahui bahwa nilai rata-rata DAR adalah 0.890 dan Standar devasi adalah 1.104 yang dimana nilai Standar deviasi lebih besar dari nilai rata-rata. Hal ini menujukan bahwa terjadinya kesenjanganan antar data yang satu dengan lainya yang menunjukan data sampel yang digunakan semakin bervariasi dari rata-ratanya. Nilai Maximum DAR adalah 5.073 ada pada perusahaan POLY pada tahun 2016 hal ini menandakan bahwa tingkat risiko hutang yang dimiliki oleh perusahaan tersebut tinggi. Sementara nilai Minimum DAR adalah 0.084 ada pada perusahaan TFCO pada tahun 2018. Hal ini menandakan bahwa tingkat risiko hutang yang dimiliki rendah.

d. Profitabilitas

Berdasarkan Variabel Profitabilitas diukur dengan menggunakan Rasio ROA atau Return On Asset. Berdasarkan hasil E-views pada 17 perusahaan Tekstil dan Garment, diketahui bahwa nilai rata-rata ROA adalah -0,018 dan standar deviasi 0,113 dimana nilai Standar deviasi lebih rendah dari rata-rata artinya tidak terjadi kesenjangan antara data satu dengan lainnya yang menandakan bahwa persebaran data sampel tidak ada kecenderungan data berbeda dengan satu dan lainnya. Nilai Maximum ROA adalah 0.141 ada perusahaan dengan kode TRIS pada tahun 2018. Hal ini menunjukan bahwa perusahaan telah mampu mencetak laba dengan baik karena nilai ROA pada perusahaan TRIS lebih tinggi dari rata-rata ROA. Sementara nilai Minimum ROA adalah -0,605 ada pada perusahaan dengan kode HDTX pada tahun 2018. Hal ini menujukan bahwa perusahaan HDTX kesulitan dalam mencetak laba karena nilai ROA HDTX lebih rendah dibandingkan nilai rata-rata ROA.

\section{Analisis Regresi Logit}

Berikut hasil dari uji analisis regresi logit:

Tabel 3. Hasil Uji Analisis Regresi Logit

\begin{tabular}{ccccc}
\hline Variable & Coefficient & Std. Error & z-Statistic & Prob. \\
\hline CR & -1.143385 & 0.490292 & -2.332051 & 0.0197 \\
\hline DAR & -0.632145 & 0.64155 & -0.985339 & 0.3245 \\
\hline ROA & 2.644242 & 6.264043 & 0.42213 & 0.6729 \\
\hline C & 5.940676 & 2.012568 & 2.951789 & 0.0032 \\
\hline McFadden R-squared & 0.308777 & & & \\
\hline Prob(LR statistic) & 0.03419 & & & \\
\hline
\end{tabular}

Sumber: E-views 10.0 (data diolah)

Berdasarkan hasil uji regresi logistik diatas maka di dapatkan persamaan regresi logistiknya yaitu:

$L n=\left(\frac{P l}{1-P l}\right) 5.940676-1.143385 C R-0,632145 D A R+2.644242 R O A$ 
Menurut angka hasil dari uji regresi logistik diatas maka di dapatkan penjelasan sebagai berikut:

a. Konstanta

Hasil konstanta dari pengujian tersebut didapat hasil sebesar 5.40676 yang menunjukan bahwa setiap 1 Financial Distress akan meningkat sebesar 5.40676 diluar pengaruh variabel independent yaitu Likuiditas, Leverage dan Profitabilitas.

b. Koefisien Regresi Likuiditas $\left(\beta_{1}\right)$

Nilai Koefisien regresi variabel likuiditas yang diukur dengan Current Asset (CR) sebesar -1.143385. Sehingga dapat diartikan bahwa setiap kenaikan Rasio Lancar sebesar 1 akan terjadinya Financial Distress disatu perusahaan akan menurun sebesar 1.143385. Dengan ini dapat diartikan bahwa Rasio Lancar memiliki hubungan Negatif dengan Financial Distress.

c. Koefisien Regresi Leverage $\left(\beta_{2}\right)$

Nilai koefisien regresi variabel Leverage yang diukur dengan Rasio DAR sebesar 0.632145. Sehingga dapat diartikan bahwa setiap kenaikan DAR sebesar 1 akan terjadinya Financial Distress disuatu perusahaan akan menurun sebesar 0.632145 . Dengan ini dapat diartikan bahwa DAR memiliki hubungan Negatif dengan Financial Distress.

d. Koefisien Profitabilitas $\left(\beta_{3}\right)$

Nilai koefisien regresi variabel Profitabilitas yang diukur dengan Rasio ROA sebesar 2.644242. Sehingga dapat diartikan bahwa setiap kenaikan ROA sebesar 1. Maka terjadinya Financial Distress disuatu perusahaan akan menurun sebesar 2.644242. Dengan ini dapat diartikan bahwa ROA memiliki hubungan Positif dengan Financial Distress.

Uji Hosmer dan Lemeshow's Goodness Of Fit Test

Tabel 4. Uji Hosmer dan Lemeshow's Godness Of Fit Test

\begin{tabular}{lllllll}
\hline \hline \multicolumn{1}{c}{ Total } & 4 & 4.00000 & 47 & 47.0000 & 51 & 1.75530 \\
\hline \hline H-L Statistic & 1.7553 & & Prob. Chi-Sq(8) & 0.9876 & \\
Andrews Statistic & 44.3251 & & Prob. Chi-Sq(10) & 0.0000 & \\
\hline \hline
\end{tabular}

Sumber :E-views 10.0 (data diolah)

Dari tabel 4 diatas diketahui bahwa nilai Probabilitas Chi Square dari H-L Statistic adalah 0.9876. hal ini menunjukan bahwa $0.9876>0,05$ artinya model penelitian ini dapat digunakan untuk menjelaskan data ataupun memprediksi nilai dari observasinya.

Uji Overall Model

Tabel 5. Uji Overall Model

\begin{tabular}{llll}
\hline LR statistic & 8.658724 & Avg. log likelihood & -0.190032 \\
\hline Prob(LR statistic) & 0.034190 & & \\
\hline Sumber $: E-$ iens $10.0($ dat diolah) & &
\end{tabular}

Sumber : E-views 10.0 (data diolah)

Dari tabel 5 diatas diketahui bahwa nilai Prob(LR Statistic) adalah 0.034190. Hal ini menunjukan bahwa 0,034190<0,05. Dengan ini dikatakan bahwa ada minimal 1 variabel independen yang dapat mempengaruhi variabel dependen

Uji Hipotesis (Uji Z)

Berikut hasil satatistik yang digunakan untuk melihat pengaruh antara variabel indEpendent dengan variabel dependent

a. Likuiditas Terhadap Finacial distress

Berdasarkan hasil pengolahan data statistik pada tabel 3. Diketahui bahwa nilai koefisien sebesar -1.143385, maka apabila nilai Likuiditas dinaikan 1 maka kemungkinan Financial Distress akan menurun sebesar 1.143385. Dari hasil pengolahan data menggunakan Eviews diatas dapat diketahui bahwa nilai z-Statistic sebesar -2.3321 dan z-tabel -1,645 artinya. Z-Statistic -2.3321< z-tabel -1.645. Dan
Financial

Performance and

Financial Distress

315 
Financial

Performance and

Financial Distress

316

nilai Probabilitas 0.0032 dan nilai $\alpha(0,05)$. Artinya Probabilitas $0.0032<0,05$. Maka

H1 diterima artinya Likuiditas berpengaruh negatif terhadap Financial Distress.

b. Leverage Terhadap Financial Distress

Berdasarkan hasil pengolahan data statistik pada tabel 3. Diketahui bahwa nilai koefisien -0.632145 , maka apabila nilai Leverage dinaikan 1 maka kemungkinan Financial Distress akan menurun sebesar 0.632145. Dari hasil pengolahan data menggunakan Eviews diatas dapat diketahui bahwa nilai z-Statistic sebesar -0.98534 dan z-tabel $-1,645$, artinya z-Statistic $-0.98534<-1.645$. Dan nilai Probabilitas sebesar 0.3245 dan nilai $\alpha(0,05)$, artinya Probabilitas $0.3245>0,05$. Maka H0 diterima artinya Leverage tidak berpengaruh terhadap Financial Distress.

c. Profitabilitas Terhadap Financial Distress

Berdasarkan hasil pengolahan data statistik pada tabel 3. Diketahui bahwa nilai koefisien 2.644242. Maka apabila dinaikan 1 maka kemungkinan financial Distress akan meningkat 2.644242. Dari hasil pengolahan data menggunakan Eviews diatas dapat diketahui bahwa nilai z-Statistic sebesar 0.42213 dan z-tabel 1,645, artinya zStatistic $0.42213<1.645$. Dan nilai Probabilitas sebesar 0.6729 dan nilai $\alpha(0,05)$, artinya Probabilitas $0.6729>0,05$. Maka H0 diterima artinya Profitabilitas tidak berpengaruh terhadap Financial Distress.

\section{Uji Koefisien Determinasi (Mc Fadden $\boldsymbol{R}^{\mathbf{2}}$ )}

Berdasarkan tabel 3. Hasil yang Koefisien McFadden $R^{2}$ yang diperoleh adalah 0.308777 . Sehingga dapat dijelaskan bahwa variabel independen di dalam penelitian ini dapat menerangkan Financial Distress sebesar 0.308777 dan sisanya 0.691223 dapat diterangkan dengan variabel independen yang lainnya.

\section{Pembahasan}

Pengaruh Likuiditas Terhadap Financial Distress

Berdasarkan hasil pengujian hipotesis pada Variabel Likuiditas diketahui bahwa $\mathrm{H} 1$ diterima. Maka artinya Likuiditas berpengaruh negatif terhadap Financial Distress. Hal lain menunjukan semakin rendah nilai likuiditas suatu perusahaan akan diindikasikan mengalami Financial Distress. Begitupula dengan sebaliknya bila nilai likuiditas tinggi maka dapat diindikasikan mengalami Financial Distress. Hasil dari perhitungan Rasio Likuiditas yang menggunakan pengukuran Current Ratio dari 17 perusahaan didapatkan bahwa nilai Likuiditas tertinggi selama periode penelitian ada pada perusahaan PBRX dengan nilai 6.457. Sehingga dikatakan bahwa perusahaan tersebut dianggap mampu dalam melunasi kewajiban jangka pendeknya. namun menurut perhitungan Altman Zscore perusahaan tersebut dalam kategori (1) atau Financial Distress. Hasil penelitian ini dukung oleh penelitian sebelumnya yang dilakukan oleh penelitian Nih Luh Putu Ari Dewi \& I Dewa Endiana (2019), Novarica Sari Indah Silalahi, Hendratno Hendratno (2019) dan Moch. Rusli 2019 yang menyatakan bahwa Likuiditas berpengaruh negatif terhadap financial distress

\section{Pengaruh Leverage Terhadap Financial Distress}

Hasil pengujian Hipotesis variabel Leverage diketahui H0 diterima. Hal tersebut menunjukan bahwa Leverage tidak berpengaruh terhadap Financial Distress. Artinya tinggi atau rendah nilai Leverage tidak mengindikasikan Financial Distress disuatu perusahaan. Perusahaan dengan hutang yang besar berisiko dengan terjadinya Financial Distress. Namun masih berpeluang mendapatkan laba yang tinggi untuk mempertahankan kondisi perusahaannya agar dapat melakukan kegiatan operasioanal. Dalam penelitian ini berbeda dengan penelitian sebelumnya yang dilakukan oleh Menurut Penelitian terdahulu dari Adhi Setyo Budhi (2017), Arie Dewanty (2018) dan Carolina Reni Damayanti (2018) Yang Mengatakan hal yang sama yaitu Leverage berpengaruh Positif terhadap Financial Distress. Hal ini bisa saja terjadi karena perbedaan tahun penelitian maupun faktor-faktor lainnya

\section{Pengaruh Pertumbuhan Penjualan Terhadap Financial distress}

Hasil pengujian Hipotesis Variabel Profitabilitas diketahui H0 diterima artinya tidak ada pengaruh antara Profitabilitas dengan Financial Distress. Hal ini menunjukan bahwa 
tinggi atau rendahnya nilai Profitabilitas tidak mempengaruhi kemungkinan adanya Financial Distress. Profitabilitas yang tinggi dapat menunjukan bahwa perusahaan tersebut telah melakukan efisiensi terhadap risiko-risiko keuangan dengan perolehan laba yang telah dicetak dengan baik. Hasil penelitian ini didukung oleh hasil penelitian yang dilakukan Ayu Dewi Ambarwati (2019), Mardyana (2018) dan Sari (2016) yang mengatakan bahwa Profitabilitas tidak berpengaruh terhadap Financial Distress

\section{PENUTUP}

Berdasarkan data analisa dan pembahasan yang telah dilakukan maka penelitian ini memiliki kesimpulan sebagai berikut:

a. Hasil pengujian variabel Likuiditas yang diukur dengan Rasio Lancar menunjukkan hasil yang menyatakan bahwa variabel Likuiditas berpengaruh Negatif terhadap Financial Distress pada perusahaan Tekstil dan garment di indonesia pada periode 2016-2018.

b. Hasil pengujian variabel Leverage yang diukur dengan Debt Equity Ratio (DAR) menunjukkan hasil yang menyatakan bahwa variabel Leverage tidak berpengaruh terhadap Financial Distress pada perusahaan Tekstil dan garment di indonesia pada periode 2016-2018.

c. Hasil pengujian variabel Pertumbuhan Penjualan yang di ukur dengan Sales Growthbahwa menunjukan hasil yang mengatakan bahwa Pertumbuhan Penjualan tidak berpengaruh terhadap Financial Distress pada perusahaan sub sektor Perdagangan Eceran (Ritel) pada periode 2016-2019 maka hipotesis penelitian ini terbukti.

\section{DAFTAR PUSTAKA}

Ardian, A. V., Andini, R., \& Raharjo, K. (2017). Pengaruh Rasio Likuiditas, Rasio Leverage, Rasio Aktifitas dan Rasio Profitabilitas Terhadap Financial Distress (pada perusahaan manufaktur yang terdaftar di Bursa Efek Indonesia periode tahun 2013-2015). Journal Of Accounting, 3(3).

Brigham, H. (2017). Dasar-Dasar Manajemen Keuangan (Ali Akbar Yulianto (ed.); Edisi 11 B). Salemba Empat.

Bursa efek ndonesia. (2020). "Laporan Keuangan Tahunan". diakses 20 Maret 2020, dari http://www.idx.co.id .

Damayanti, C. R., \& Kawedar, W. (2019). Pengaruh Profitabilitas, Mekanisme Pemantauan Dan Financial Distress Terhadap Manajemen Laba. Diponegoro Journal of Accounting, 7(4).

Davista, A. (2018). "Pengaruh Likuiditas, Leverage dan Profitabilitas terhadap Financial Distress Perusahaan Manufaktur yang terdaftar di Bursa Efek Indonesia" (Doctoral dissertation, Universitas Negeri Padang).

Dewanty, A. P. A., Putra, I. N. N. A., \& Hidayati, S. A. (2018). Pengaruh Likuiditas Dan Leverage Terhadap Financial Distress Pada Perusahaan Perdagangan, Pelayanan Jasa Dan Investasi Yang Terdaftar Di BEI Tahun 2016-2017. JMM UNRAM-UNRAM MANAGEMENT REVIEW, 7(3), 78-94.

Dewi, N. L. P. A., Endiana, I. D. M., \& Arizona, I. P. E. (2019). Pengaruh Rasio Likuiditas, Rasio Leverage Dan Rasio Profitabilitas Terhadap Financial Distress Pada Perusahaan Manufaktur. Kumpulan Hasil Riset Mahasiswa Akuntansi (KHARISMA), 1(1), 322-333.

Fatimah, F., Toha, A., \& Prakoso, A. (2019). "The Influence of Liquidity, Leverage and Profitability Ratio on Finansial Distress". Owner, 3(1), 103-115.

Ghozali, I. (2013). Aplikasi Analisis Multivariate dengan Program IBM SPSS 21. Semarang: Badan Penerbit Universitas Diponegoro.

Hidayati, N. (2019). "The Effect Of Financial Distress, Audit Client Tenure And Debt Default On. Journal Of Management."
Financial

Performance and

Financial Distress

317 
Financial

Performance and

Financial Distress

318
Kusuma, E., \& Sumani, S. (2017). Pengaruh likuiditas, leverage dan profitabilitas terhadap financial distress (Z-Score) perusahaan property, real estate, dan manufaktur periode 20142016. Jurnal Manajemen, 14(1), 1-16.

Lubis, A. F. (2019). Analisis Pengaruh Rasio Likuiditas, Rasio Leverage Dan Rasio Profitabilitas Terhadap Financial Distress Pada Perusahaan Infrastruktur, Utilitas Dan Transportasi Yang Terdaftar Di Bei (Doctoral dissertation, Universitas Pembangunan Nasional Veteran Jakarta).

Makiwan, Gischanovelia (2018). Analisis Rasio Leverage Untuk Memprediksi Pertumbuhan Laba Perusahaan Manufaktur Sub Sektor Makanan Dan Minuman Yang Terdaftar Di Bursa Efek Indonesia Periode 2011-2015. JBMI (Jurnal Bisnis, Manajemen, dan Informatika). 15. 147. 10.26487/jbmi.v15i2.3530.

Mas'ud, I., \& Srengga, R. M. (2015). Analisis Rasio Keuangan Untuk Memprediksi Kondisi Financial Distress Perusahaan Manufaktur Yang Terdaftar Di Bursa Efek Indonesia. Jurnal Akuntansi Universitas Jember

Nugroho, K. N. P., \& Hidayat, R. R. (2016). Pengunaan Analisis Z-Score Altman Untuk Menilai Tingkat Financial Distress (Studi Pada Perusahaan Tekstil Dan Garmen Yang Terdaftar Di Bursa Efek Indonesia Periode 2011-2014). Jurnal Administrasi Bisnis, 36(1), 20-29.

Rialdy, Novien. (2018). Analisis Prediksi Kebangkrutan Dengan Menggunakan Metode Altman Z-Score Pada Pt. Adhi Karya (Persero) Tbk. 9. 79 - 96.

Rizki, N. D. (2019). Pengaruh Rasio Keuangan Terhadap Probabilitas Terjadinya Financial Distress Pada Perusahaan Keluarga Yang Terdaftar di Bursa Efek Indonesia.

Rohmadini, A., Saifi, M., \& Darmawan, A. (2018). Pengaruh Profitabilitas, Likuiditas Dan Leverage Terhadap Financial Distress (Studi Pada Perusahaan Food \& Beverage Yang Terdaftar Di Bursa Efek Indonesia Periode 2013-2016). Jurnal Administrasi Bisnis, 61(2), 11-19.

Rusli, M. (2019). Pengaruh Profitabilitas, Likuiditas, Dan Solvabilitas Terhadap Financial Distress Pada Perusahaan Manufaktur Yang Terdaftar Di Bursa Efek Indonesia (Bei) Periode Tahun 2015-2017 (Doctoral dissertation, Universitas Negeri Jakarta).

Sari, I. P., Susbiyani, A., \& Syahfrudin, A. A. (2019). Analisis Faktor- Faktor Yang Mempengaruhi Kondisi Financial Distress Pada Perusahaan Yang Terdapat Di Bei Tahun 2016-2018 (Studi Empiris pada Perusahaan Manufaktur Sub Sektor yang Terdaftar di Bursa Efek Indonesia). Jurnal Ilmiah Akuntansi dan Humanika, 9(2).

Setyobudi, A., Amboningtyas, D., \& Yulianeu, Y. (2017). The Analysis Of Liquidity, Leverage, Profitability, And Firm Size Influence Toward The Financial Distress With Good Corporate Governonce As The Moderating Variable In Pt. Telekomunikasi Indonesia Tbk. And Pt. Indosat Tbk. Journal of Management, 3(3).

Siagian, I. B., \& Rusliati, H. E. (2018). Analisis Kinerja Keuan Gan Sebelum Dan Sesudah Restrukturisasi Modal Pada Pt. Kertas Padalarang Tahun 2013 (Doctoral dissertation, Fakultas Ekonomi dan Bisnis Unpas)

Silalahi, N. S. I., \& Hendratno, H. (2019). Pengaruh Rasio Likuiditas, Rasio Leverage, Dan Rasio Profitabilitas Terhadap Financial Distress (studi Kasus Pada Perusahaan Subsektor Property Dan Real Estate Yang Terdaftar Di Bei Tahun 2012-2016). eProceedings of Management, 6(2).

Syamsuddin, L. (2016). Manajemen Keuangan Perusahaan. Dalam Manajemen Keuangan Perusahaan:Konsep Aplikasi dalam Perencanaan,Pengawasan,dan Pengambilan Keputusan (hal. 192). Jakarta: PT Raja Grafindo Persada.

Viggo, E. (2014). Pengaruh Financial Leverage dan Firm Growth Terhadap Financial Distress.FINESTA.2(2).6-11

Wicaksono, A. Y. (2018). Pengaruh leverage, likuiditas, profitabilitas dan pertumbuhan penjualan terhadap financial Distress sektor properti dan real Estate yang terdaftar di bei (Doctoral dissertation, STIE PERBANAS SURABAYA). 